\title{
HUBUNGAN PERSALINAN PRETERM PADA PREEKLAMPSIA BERAT DENGAN FETAL OUTCOME DI RSU ISLAM HARAPAN ANDA TEGAL
}

\author{
Putra, A.N.E. ${ }^{1}$, Hasibuan, H.S. ${ }^{2}$ Fitriyati, Y. ${ }^{2}$ \\ ${ }^{1}$ Mahasiswa Pendidikan Dokter Fakultas Kedokteran Universitas Islam Indonesia \\ ${ }^{2}$ Departemen Obstetri dan Ginekologi Fakultas Kedokteran Universtas Islam Indonesia
}

\begin{abstract}
ABSTRAK
Latar Belakang

Persalinan preterm masih merupakan masalah baik di negara berkembang maupun di negara maju oleh karena dapat menyebabkan banyak risiko antara lain kematian bayi. Preeklampsia menjadi salah satu penyebab tersering persalinan preterm dan kematian perinatal yang diketahui selama ini.
\end{abstract}

\section{Tujuan Penelitian}

Tujuan dari penelitian ini adalah untuk mengetahui hubungan antara fetal outcome (kematian perinatal, asfiksia dan berat badan bayi) pada persalinan preterm yang disertai preeklampsia berat.

\section{Metode penelitian}

Penelitian ini merupakan studi non eksperimental dengan desain cross sectional. Subjek penelitian adalah ibu yang melahirkan secara preterm yang memenuhi kriteria inklusi dan eksklusi sebanyak 75 orang. Subjek terbagi dalam kelompok terpapar yaitu ibu yang preeklampsia berat dan kelompok kontrol yaitu ibu yang tidak dengan preeklampsia berat. Pengumpulan data dilakukan dengan mengambil data sekunder dari rekam medis. Pengelolaan data menggunakan SPSS dengan uji Chi-Square. Sampel penelitian didapatkan 40 orang sebagai kelompok terpapar dan 35 orang sebagai kelompok kontrol.

\section{Hasil}

Analisis bivariat menunjukkan terdapat perbedaan yang signifikan antara kelompok terpapar dan kelompok kontrol pada kejadian kematian perinatal $(p=0,013)$ dan pada kejadian asfiksia $(p=0,00)$. Sedangkan pada kejadian BBLR tidak terdapat perbedaan yang signifikan antara kelompok terpapar dan kelompok kontrol $(p=0,745)$.

\section{Kesimpulan}

Terdapat hubungan yang signifikan antara persalinan preterm disertai preeklampsia berat dengan fetal outcome, yaitu kematian perinatal dan asfiksia, serta tidak ditemukan perbedaan BBLR antara kelompok terpapar dan kelompok kontrol.

Kata Kunci : preterm, preeklampsia berat, fetal outcome. 


\section{ABSTRACT}

\section{Background}

Preterm delivery has not only become a problem in developed country but also become a problem in developing country. Preterm delivery is among the top causes of death in infants One of the most important risk factors in preterm delivery is preeclampsia.

\section{Objective}

To find out the relationship between fetal outcomes (perinatal death, asphyxia and baby weight) in preterm labor and severe preeclampsia

\section{Methods}

This was a cross-sectional study. Seventy-five preterm birth mothers were included in this study. Subjects were divided into two groups. Group I (40 subjects): Subjects were severe preeclampsia and Group II (35 subjects) were mothers without severe preeclampsia. Data were obtained through medical records. The trial was analyzed using a Chi-Square test. Bivariate analysis was applied to obtain magnitude of association between independent variables and preterm birth.

\section{Results}

The bivariate analysis showed that there was significant differences between the exposed and control groups in the incidence of perinatal death $(p=0.013)$ and the incidence of asphyxia $(p-=0)$. The incidence of low birth weight was not a significant difference between the exposed and control groups $(p=0.745)$.

\section{Conclusions}

There was a significant relationship between preterm birth on severe preeclampsia with fetal outcome, perinatal death and asphyxia. In fetal outcomes of low birth weight was not found significant differences between the exposed and control groups.

Keywords: preterm, severe preeclampsia, fetal outcome, perinatal death, asphyxia, low birth weight

\section{PENDAHULUAN}

Salah satu indikator derajat kesehatan masyarakat adalah angka kematian bayi atau kematian perinatal, dimana di Indonesia prosentasenya masih tinggi. ${ }^{1}$ Penyebab angka kesakitan dan angka kematian tersebut terbanyak karena persalinan preterm. $^{2}$ Persalinan preterm menyebabkan banyak risiko karena usia bayi dalam kandungan kurang dari 37 minggu. Tidak hanya di Indonesia, kelahiran bayi preterm ini juga masih merupakan masalah bagi negara maju. ${ }^{3}$ Preterm menyebabkan kematian sampai $28 \%$ bayi baru lahir. ${ }^{4}$ Salah satu penyebab tersering persalinan preterm dan kematian perinatal yang diketahui selama ini adalah preeklampsia, selain faktor yang lain yaitu 
usia ibu, kehamilan ganda, infeksi, penyakit kronis dari ibu seperti diabetes melitus, tiroid, anemia, malnutrisi, dan banyak faktor karena janin. ${ }^{4}$

Anak yang dilahirkan oleh ibu penderita preeklampsia mempunyai berat badan yang rendah, dan mempunyai risiko kematian yang tinggi pada periode neonatus. $^{2}$ Insidensi preeklampsia 5-7\% dari seluruh kehamilan, namun kejadian kematian neonatal pada preeklampsia dengan kehamilan preterm sekitar 23\%. Hal ini karena preeklampsia merupakan penyakit pada kehamilan yang menyebabkan perfusi darah ke organ berkurang serta adanya vasospasme dan menurunnya aktivitas sel endotel. ${ }^{6}$

Penanganan eklampsia yang tidak baik meningkatkan risiko kematian ibu. ${ }^{4} \mathrm{Ibu}$ dengan eklampsia dapat mengalami gejala disseminated intravascular coagulation (DIC), gagal ginjal akut, stroke, sindrom HELLP. ${ }^{7}$ Untuk mengurangi risiko kematian ibu akibat hal ini, penatalaksanaan eklampsia diantaranya terminasi kehamilan, atau kelahiran preterm atas indikasi. ${ }^{4}$

Eklampsia menyebabkan penghambatan pertumbuhan janin dalam kandungan, kematian intrauterin, berat badan bayi lahir rendah, penurunan APGAR score dan peningkatan kebutuhan bayi masuk ke neonatal intensive care unit (NICU). ${ }^{8}$

Mengetahui fetal outcome karena preeklampsia penting diketahui untuk memungkinkan intervensi pencegahan dan penatalaksanaan preeklampsia yang tepat. Tujuan dari penelitian ini adalah untuk mengetahui hubungan antara fetal outcome pada persalinan preterm disertai preeklampsia berat yang mencakup kematian perinatal, asfiksia dan berat badan bayi.

\section{METODE PENELITIAN}

Penelitian ini adalah studi non eksperimental yang bertujuan untuk mengetahui hubungan antar variabel dengan desain penelitian cross sectional. Subjek penelitian ini akan dibagi menjadi dua kelompok. Kelompok I adalah pasien yang melahirkan secara preterm dan disertai preeklampsia berat Sedangkan kelompok kontrol (II) terdiri atas pasien yang melahirkan secara preterm tanpa disertai preeklampsia berat. Kedua kelompok tersebut dinilai fetal outcomenya yang berupa kematian perinatal, asfiksia dan berat badan bayi.

Populasi yang akan diteliti adalah ibu yang melahirkan secara preterm di Rumah Sakit Umum Islam (RSUI) Harapan Anda kota Tegal. Cara pengambilan sampel 
adalah seluruh data rekam medis yang memenuhi kriteria inklusi dan eksklusi dalam kurun waktu 2 tahun (Januari 2011 Desember 2012). Sebagai kriteria inklusi sampel penelitian adalah: a) ibu hamil yang melahirkan secara preterm, b) bayi lahir spontan dan tunggal, c) usia kehamilan preterm 28 sampai 36 minggu dan d) antenatal care minimal 4 kali. Sedangkan yang menjadi kriteria eksklusi adalah: a) mempunyai riwayat penyakit sistemik seperti diabetes, hipertiroid, hipotiroid, ginjal, jantung dan hati, b) terdapat kelainan kongenital mayor pada bayi, c) persalinan dengan tindakan sectio caesare atau vakum ekstraksi karena dapat mempengaruhi fetal outcome.

\section{HASIL DAN PEMBAHASAN}

Penelitian dan pengambilan data dilakukan di Rumah Sakit Umum Islam Harapan Anda Tegal pada bulan Januari
2013. Didapatkan total kelahiran pada periode Januari 2011 sampai dengan Desember 2012 berjumlah 3194 kelahiran. Total persalinan preterm berjumlah 364 persalinan, persalinan preterm yang disertai preeklampsia berat berjumlah 92 persalinan, yang secara spontan berjumlah 69 persalinan dan yang melalui sectio caesarea berjumlah 23 persalinan. Sedangkan yang tidak disertai preeklampsia berat berjumlah 272 persalinan, yang secara spontan berjumlah 217 persalinan dan yang melalui sectio caesarea berjumlah 55 persalinan. Untuk kelahiran preterm dari ibu preeklampsia berat diambil 40 kasus sebagai kelompok terpapar dan dari bukan preeklampsia diambil 35 kasus sebagai kelompok kontrol (Tabel 1). Karakteristik subjek penelitian berdasarkan usia ibu, usia kehamilan, dan paritas tampak sama antara kelompok terpapar dan kelompok kontrol.

Tabel 1. Karakteristik Subjek Penelitian

\begin{tabular}{lccc}
\hline \multirow{2}{*}{ Variabel } & & \multicolumn{3}{c}{ Frekuensi } \\
\cline { 2 - 4 } & & $\begin{array}{c}\text { Kelompok preterm dengan } \\
\text { ibu preeklampsia berat } \\
\text { N }(\%)\end{array}$ & $\begin{array}{c}\text { Kelompok preterm tanpa } \\
\text { preeklampsia berat } \\
\mathbf{N}(\%)\end{array}$ \\
\hline \multirow{3}{*}{ Usia ibu (tahun) } & $\leq 20$ & $2(5)$ & $6(17,15)$ \\
\cline { 2 - 4 } & $21-34$ & $25(62,5)$ & $23(65,7)$ \\
\cline { 2 - 4 } $\begin{array}{l}\text { Usia kehamilan } \\
\text { (minggu) }\end{array}$ & $28-33$ & $13(32,5)$ & $6(17,15)$ \\
\hline \multirow{2}{*}{ Paritas } & $34-36$ & $13(32,5)$ & $12(34,3)$ \\
\cline { 2 - 4 } & Primigravida & $27(67,5)$ & $18(65,7)$ \\
\hline & Multigravida & $16(40)$ & $17(48,6)$ \\
\hline
\end{tabular}


Tabel 2. Hubungan antara Persalinan Preterm disertai PEB dengan Luaran Perinatal

\begin{tabular}{|c|c|c|c|c|c|}
\hline \multirow{2}{*}{ Variabel } & \multicolumn{2}{|c|}{ Luaran perinatal } & \multirow[t]{2}{*}{$\%$} & \multirow{2}{*}{$\begin{array}{c}\mathrm{RR} \\
95 \% \mathrm{CI} \\
\end{array}$} & \multirow[t]{2}{*}{$\mathbf{p}$} \\
\hline & Mati & Hidup & & & \\
\hline Preterm dengan PEB & 16 & 24 & 40 & 2,8 & \\
\hline Preterm Non PEB & 5 & 30 & 14,3 & $1,143-6,859$ & 0,013 \\
\hline
\end{tabular}

akibatnya bayi mudah mengalami sindrom distres respirasi. Berat badan bayi cenderung kurang, karena gangguan aliran darah plasenta, bayi mudah mengalami necrotizing enterocolitis dan infeksi karena netropenia. Bayi dengan ibu eklampsia mengalami trombositopemia sehingga bayi mudah mengalami perdarahan dan peningkatan risiko ensefalopati. ${ }^{11}$

Persalinan preterm disertai preeklampsia berat meningkatkan risiko dalam paru-paru bayi. ${ }^{13}$ kardiovaskular berupa kejang arteriol yang dapat mengganggu aliran darah uteroplasenta dan dapat menyebabkan asfiksia berat tiba-tiba. Jika kejang berlangsung lama, maka akan mengganggu pertumbuhan janin, jika ada peningkatan tonus uterus dan kepekaan terhadap rangsangan, mungkin menyebabkan partus prematur. Selain itu, risiko asfiksia juga dikaitkan dengan kekurangan surfaktan dalam paru-paru bayi.

Tabel 3. Hubungan antara Persalinan Preterm disertai PEB dengan Asfiksia

\begin{tabular}{|c|c|c|c|c|c|}
\hline \multirow{2}{*}{ Variabel bebas } & \multicolumn{2}{|c|}{ Nilai APGAR 5 menit } & \multirow[b]{2}{*}{$\%$} & \multirow{2}{*}{$\begin{array}{c}\text { RR } \\
95 \% \mathrm{CI}\end{array}$} & \multirow[b]{2}{*}{$\mathbf{p}$} \\
\hline & Asfiksia & Non-asfiksia & & & \\
\hline Preterm dengan PEB & 18 & 22 & 45 & 7,875 & م 0 \\
\hline Preterm Non-PEB & 2 & 33 & 5,7 & $1,964-31574$ & 0,00 \\
\hline
\end{tabular}

terjadinya asfiksia pada janin sebesar 7,875 kali (95\% CI : 1,964-31,574). Menurut Dina $^{12}$ kejadian asfiksia meningkat pada preeklampsia berat. Pada penelitian Lestari $^{10}$ asfiksia memberikan risiko relatif sebesar 7,56 kali (95\% CI : 3,524-16,200). Pada preeklampsia terjadi spasme pembuluh darah dan peningkatan tekanan darah, terjadi perubahan sistem
Hasil penelitian menunjukkan neonatus dengan ibu eklampsia mengandung sel darah merah berinti lebih banyak dibandingkan neonatus normal dan kondisi ini dihubungkan dengan kejadian asfiksia. $^{14}$ Perlu dipikirkan indikasi penanganan kelahiran ibu dengan eklampsia. Penelitian oleh Begum et al. ${ }^{15}$ menunjukkan persalinan pervaginam lebih 
Tabel 4. Hubungan Persalinan Preterm disertai PEB dengan Berat Badan Bayi

\begin{tabular}{lccccc}
\hline Variabel & \multicolumn{2}{c}{ Nilai APGAR 5 menit } & \% & RR & p \\
& BBLR & Non-BBLR & & $\mathbf{9 5 \%}$ CI & \\
\hline Preterm dengan PEB & 32 & 8 & 80 & 1,077 & \multirow{2}{*}{0,555} \\
Preterm Non-PEB & 26 & 9 & 74,3 & $0,840-1,381$ & \\
\hline
\end{tabular}

Tabel 5. Hubungan antara Usia Kehamilan Kelompok Terpapar dengan Berat Badan Bayi

\begin{tabular}{|c|c|c|c|c|c|}
\hline \multirow{2}{*}{$\begin{array}{c}\text { Usia kehamilan } \\
\text { (tahun) }\end{array}$} & \multicolumn{2}{|c|}{ Berat badan bayi } & \multirow[t]{2}{*}{$\%$} & \multirow{2}{*}{$\begin{array}{c}\text { RR } \\
95 \% \mathrm{CI} \\
\end{array}$} & \multirow[t]{2}{*}{$\mathbf{p}$} \\
\hline & BBLR & Non-BBLR & & & \\
\hline 28-33 & 13 & 0 & 100 & 1,421 & 0028 \\
\hline 34-36 & 19 & 8 & 70,4 & $1,113-1,815$ & 0,020 \\
\hline
\end{tabular}

banyak menimbulakn asfikisia neonatus dibandingkan dengan cesar.

Pada penelitian ini tidak tampak hubungan antara persalinan preterm disertai preeklampsia berat dengan risiko kelahiran bayi rendah, $\mathrm{RR}=1,077$ (95\% $\mathrm{CI}: 0,840$ 1,381). Penelitian sebelumnya oleh Wahyuni, ${ }^{16}$ Lestari $^{10}$ dan Siza $^{17}$ menunjukkan terdapat hubungan antara preeklampsia berat dengan kejadian berat menunjukkan tidak ada perbedaan fetal outcome pada preeklampsia dengan kelahiran prematur menurut evidence-based dan non evidence-based jika usia kehamilannya sama.

\section{KESIMPULAN}

Dapat disimpulkan dari penelitian ini bahwa terdapat hubungan yang signifikan antara persalinan preterm disertai

Tabel 6. Hubungan antara Usia Kehamilan Kelompok Kontrol dengan Berat Badan Bayi

\begin{tabular}{cccccc}
\hline $\begin{array}{c}\text { Usia kehamilan } \\
\text { (tahun) }\end{array}$ & \multicolumn{2}{c}{ Berat badan bayi } & \% & RR & p \\
\hline $\mathbf{2 8 - 3 3}$ & BBLR & Non-BBLR & & $\mathbf{9 5 \%}$ CI & \\
\hline $\mathbf{3 4 - 3 6}$ & 12 & 0 & 100 & 1,643 & \multirow{2}{*}{0,012} \\
\hline
\end{tabular}

badan bayi rendah (BBLR). Preeklampsia berat meningkatkan kejadian BBLR dan risiko relatifnya sebesar 8,46 kali $(95 \% \mathrm{CI}$ : 3,538-20,231). ${ }^{10}$ Adanya BBLR bisa disebabkan karena preeklampsia berat terjadi pada umur kehamilan yang lebih muda (Tabel 5 dan 6). Penelitian yang dilakukan oleh Gyamfi-Bannerman et al. ${ }^{18}$ preeklampsia berat dengan fetal outcome, yaitu kematian perinatal dan asfiksia. Pada fetal outcome BBLR tidak ditemukan perbedaan yang signifikan antara kelompok terpapar dan kelompok kontrol. 


\section{DAFTAR PUSTAKA}

1. Departemen Kesehatan RI. Sistem Kesehatan Nasional. Jakarta. 2009.

2. Lawn JE, Cousens S, Zupan J. 4 million neonatal deaths: when? Where? Why? Lancet, 2005;365:891-900.

3. Howson CP, Kinney MV, Lawn JE (Eds.). Born too soon: The global action report on preterm birth. World Health Organization, Geneva (2012).

4. Blencowe1 H, Cousens S, Chou D, Oestergaard M, Say L, et al. Born Too Soon: The global epidemiology of 15 million preterm births. Reproductive Health 2013, 10(Suppl 1):S2

5. Sulchan S, Preeklampsia-eklampsia di beberapa rumah sakit di Indonesia: Patogenesis dan kemungkinan pencegahannya, Pidato Pengukuhan Jabatan Guru Besar Fakultas Kedokteran Universitas Gadjah Mada, 2003

6. Steegers EA, von Dadelszen P, Duvekot JJ, Pijnenborg R. Preeclampsia. Lancet 2010;376(9741):631-44.5.

7. Ndaboine EM, Kihunrwa A, Rumanyika R, Beatrice $\operatorname{Im~H}$, Anthony N, Massinde1. Maternal and Perinatal Outcomes among Eclamptic Patients Admitted to Bugando Medical Centre, Mwanza, Tanzania Afr J Reprod Health 2012; 16[1]:35-41).

8. Ayaz A, Muhammad T, Hussain SA, Habib S. Neonatal Outcome In Pre-Eclamptic Patients. J Ayub Med Coll Abbottabad 2009;21(2).

9. Jantasing S., Tanawattanacharoen S., 2008. Perinatal Outcomes in Severe Preeclamptic Women between $24-33^{+6}$ Weeks' Gestation. J Med Assoc Thai 2008; 91 (1): 25-30.

10. Lestari DE. Analisis hubungan antara Sindrom HELLP pada preeklampsia berat dengan fetal outcome di RSUP dr. Sardjito, Fakultas Kedokteran UGM, 2006.
11. Rugolo, LMSD, Bentlin MR, Trindade CEP. Preeclampsia: Effect on the Fetus and Newborn. NeoReviews 2011;12; 198.

12. Dina S. Luaran Ibu dan Bayi Pada Penderita Preeklampsia Berat dan Eklampsia dengan atau Tanpa Sindroma Hellp. Bagian Obstetri dan Ginekologi FK USU. 2003.

13. Lee ACC, Mullany LC, Tielsch JM, Katz J, Khatry SK, LeClerq SC, et al. Risk Factors for Neonatal Mortality due to Birth Asphyxia in Southern Nepal A Prospective, Community-based Cohort Study. Pediatrics 2008; 121(5): e1381-e1390.

14. Bayram F, Ozerkan K, Cengiz C, Develioğlu O, Cetinkaya M. Perinatal asphyxia is associated with the umbilical cord nucleated red blood cell count in preeclamptic pregnancies. J Obstet Gynaecol. 2010;30(4):383-6.

15. Begum S, Islam F, Akter A, et al., Fetomaternal Outcomes in Cesarean Section Compared to Vaginal Delivery in Eclamptic Patients in a Tertiary Level Hospital. J Enam Med Col 2013; 3(2): 77 83.

16. Wahyuni. A, Rachmawati F. N. Hubungan Preeklampsia Berat Pada Ibu Hamil terhadap BBLR di RSUP Dr. Sardjito Yogyakarta Periode Tahun 2005. 2007;8(1):52-57.

17. Siza JE. Risk factors associated with low birth weight of neonates among pregnant women attending a referral hospital in northern Tanzania. Tanzania Journal of Health Research 2008;10(1):1-8.

18. Gyamfi-Bannerman C, Fuchs KM, Young $\mathrm{OM}$, et al. Nonspontaneous late preterm birth: etiology and outcomes. Am J Obstet Gynecol 2011;205:456.e-6. 